\title{
THE FETISH OF VIRTUOSITY
}

\author{
By J. N. BURK
}

$\mathbf{P}$

EOPLE are growing more and more inclined to yawn at those unhuman creatures in pink tights that, with a superlative skill acquired by life-long practice, perform balancing feats which are entirely inane and uninteresting. These unfortunate folk have devoted their lives to diverting the public, gauging the course of their activities naturally and necessarily by the amount of applause which each "turn" receives. But the public, once delighted and thrilled, has become sophisticated; it ceases to be fooled by the pretense of danger and difficulty, and turns away, bored. Hence, the acrobatic acts are now termed, in the lingo of continuous vaudeville, "chasers;" they are used to discourage tight sitters, and clear the seats for new comers. So, the victims of a whim find their life-work suddenly become imbecilic, with nothing to show for their arduous and wearisome training but unnatural and cumbersome muscles.

In that more pretentious world of the concert-halls, which maintains a more hushed and dignified sense of its own importance, there are acrobats, too, acrobats of the piano and violin, with a remarkable skill acquired in exactly the same manner, but the magic spell of culture calls them "virtuosi," and their skill, "technique," with the help of which distinguished passwords the same human need for diversion goes under the name of high art. The most essential difference between the two forms of entertainment is that the one public is disillusioned as to the tricks, and looks elsewhere for something not so entirely devoid of sense as skill for skill's sake, while the other public flocks to the lure of billboards and world renown, pays enormous sums, and beholds, in puerile wonderment and delight, feats which dazzle, and leave in their wake little more than a tingle of stupefaction. This public, which we know so well, seems highly satisfied with that contemptible institution, the concertowith rare exceptions, a mere show case, wherein the soloist may spread forth his technical jewels baldly on black velvet, to be appraised by the connoissueurs. It cares little for a magnificent orchestra, but mainly for the soloist who tries to outdo them in what might be called the birth-struggle between a sonata and a 
symphony, and who performs cadenzas of scales, arpeggios, glissandi, or harmonics, while the great orchestra sits as patiently as may be with their instruments idle, and ready to lend volume to a closing flourish when it is all over. It is not at all unlike the other acrobats' way of erecting a final symmetrical structure of arms and legs, shooting off two pistols, and unfurling an American flag with their feet, that the audience, both awake and asleep, may be aroused by patterns, patriotism, and noise, to reactionary applause. An orchestra is even better equipped for this physiological ruse-Mozart once admitted writing clamorous endings "for long ears." And applause is the guiding and final ambition of more than one virtuoso of our time. Concertos are so gratifying to the sense of bedazzlement, the impression of difficulty by facile means-in short, they are so eminently useful for the successful exploitation of everything that the virtuoso holds most dear, that he must transport his violin concertos into his recitals, and further stultify an already hybrid concoction by transcribing the "tutti" and completely destroying the balance.

You might admit limb-twisting and finger-twisting alike to be mere forms of passing amusement, and treat them lightly in the degree of their insignificance,-value trills, arabesques, and the like for their beauty of tone, nicety of poise, and the breathless charm of faultless and deft execution, a glorified sleight of hand, you might say. It is also true that the satisfaction in technical mastery is legitimate in its place and degree. But in the exaggeration of it, what a cruelly long and exacting stretch of endless practice and toil this passing sparkle of mild pleasure represents! Even if you are willing to let amusing triviality pass under the name of music, you should stop to consider the result of sanctioning and setting up an unnecessarily high standard of technique, far above the normal requirements of a sane and reasonable art. Difficulties are contrived actually for the mere purpose of conquering them, so insuperably beyond the means of human fingers that the merest handful of the world musicians can master them. The valuators sit in hawklike alertness, that they may decry and denounce the slightest flaw or slur, and in turn gratify their pride of discernment and refinement of perception. Look, once, at what the virtuoso,-so driven, usually makes of himself and his career. For if the acrobat of vaudeville is, in his street clothes, a crabbed, stuffy, and freakish individual, the musical acrobat is in most cases all this and more. Where the first has had to, spend some eight hours a day in the confinement of practice and abnormal development, the second has 
had to spend nine or ten hours a day in the attainment of a far more exacting skill. To keep primed to this perfection, once attained, means still more of those long, unceasing hours of tireless practice. The victim of the custom is narrow, unintelligent, and unhuman (musically speaking at least) because, whereas the art of music demands first of all breadth of mind and heart for its realization and communication, the virtuoso is steeped in technicalities and choked by them. His entirely absorbing work is unintelligent, unconnected with any normal human activity. $\mathrm{He}$ aims to hold his audience, not solely by the power of music, but by the power of necromancy, in which interest he cultivates "personality" which his music alone should express, and various oddities, aping the more genuine and less conscious figures of Victorian romantic times. Such oddities, under the name of "temperament," have also advertising values, and, instead of the gold teeth of his brethren, he comes forth in long, greasy. hair. It all goes to the production of freaks at the opposite pole from true art, which is, first of all, normal and healthy. As the athletes of the open air find more zest in life, and make more agreeable and beneficial human beings in our society than the acrobats with the bulging biceps which are useless off the stage, so the true, likable, and active-minded musician perceives the ultimate values of music to be simple, persuasive, and the bond of the race in a common love. Nor will he care laboriously to develop several extra joints in his thumb while learning to perform the "Erlkönig" on the piano with the left hand alone.

In this matter, history is a dangerous resource whereby to justify the present, for the history of music is also the history of perversions, corruptions and enslavements. Virtuosity dates back to the period when musicians, composers included, depended upon the patronage and nod of nobility for their very existence, when musicians and tumblers and fantastics were on the same social level, and had severally to contort themselves, and exhibit skill when bidden. Beethoven was the rebel who brought music to its rights. Then came the famed romantic virtuosi, who left behind them, for the most part, nothing more than rather tiresome anecdotes and decidedly tiresome concertos. Paganini, popularly passing for the greatest of violinists, may not improbably have been inferior to more than one of to-day, who, with the generally high standards of execution, might very conceivably "play him down," according to the old custom. The Paganini of biographical data was a charlatian in every sense. He was uneducated and immoral, he spread reports of his league with 
the devil because they brought him fame and riches, he cultivated mannerisms in his playing, and, in all but his own compositions, showed a sad lack of musical taste; finally, he left behind him a stupendous fortune and a bastard, and did his very best to carry to his grave the jealously guarded secret of his harmonics (his only permanent gift to the world). The complex character of Liszt makes another story than this. Of his many sides, the rôle of virtuoso, the foremost to assure him contemporary fame, has resulted in considerable addition to pianistic usage, and a horde of piano compositions which eloquently bespeak their own limitations.

As for the questionable place of concertos in present musical life, their doom lies in the fact that none are made now-a-days by composers of importance, and any stylistic change since the Lisztian times has been of the slightest. So, we can do no more than hasten their extinction. They are numerously and extensively performed only from the mistaken idea that orchestras must have soloists, and are generally of negligible interest to musical people otherwise than technical and competitive preoccupations among pianists and violinists themselves. Exceptions, such as one or two from Beethoven, Schumann, or Brahms, are great in spite of their form rather than because of it, and represent the least creative efforts of the respective composers; cases of the force of creating genius conquering resistant materials by the impetus of its own drive. To probe again to the sources, the fifty concertos recorded from the facile, swift, and obliging pen of the hard pressed Mozart, have practically passed from concerts. Under courtesy to one virtuoso or another, the remarkable Mozart learned to dash one off in a day or two at will, with as little waste of inspiration and divine exuberant vitality as possible, between the precious hours concentrated upon a masterpiece. With Haydn, they were similarly a matter of routine. Your Tschaikowsky or Brahms, less possessed of that supreme insight which grasps not only the significance but the insignificance of things, worried away weary months over putting them together, haranguing the publishers, and anxiously consulting fries:ds and conductors. Tedious are the results of the wise and conscientious heads of Brahms and Joachim bowed laboriously over more than one manuscript. But concertos have always served primarily to keep the pot boiling. As final evidence of their unimportance, among the surviving concertos those of the masters hold equal favor with those by numerous musicians who could write for the advantageous display of their instruments, but possessed 
nothing more than a commonplace and conventional utility, from an orchestral or broadly musical point of view: Vivaldi, Vieuxtemps, Spohr, Bruch, Viotti, Saint-Saëns, Chopin, Rubinstein, Paderewski-the list goes on indefinitely. Their names are perpetuated because of the tradition of having soloists, and the need of diversion at orchestral concerts. Soloists take up the time and efforts of an orchestra, which should be devoted to valuable orchestral music; they break up the continuity and character of the most carefully compiled programme, and they bring with them for the most part worthless scores: it is not an overstatement to say that there is no violin concerto of better than third-rate order (violinists would be lost without that very useful one by Beethoven); 'cello or double concertos, most of us openly or secretly dread.

For the rest, no genius has ever happily combined pianistic and orchestral tone, and none ever will. Here is a chance to reduce to its fundamentals by specific example a matter that must cause uneasiness in more than one concert-goer: namely, the suspicion that the over-used pianoforte is a tonally selfsufficing instrument, which has never made a completely satisfactory background to other colors or taken any background but its own; that its system of values is thrown askew in a concerto, with "tinny" results; that orchestral clarity is similarly blurred by the complex vibrations from the box of strings. To bring the question to a direct test, let us reduce the number of concertos in existence to those of the rare geniuses who worked instinctively and creatively in the two media. This leaves, under strict judgment, only Beethoven and Liszt. Concertos from the two composers are few. Liszt's two rhapsodic color-riots are revels in extravagant strokes and contrasts, extreme examples of the abbe's habit of key board orchestration, peculiar to himself, and with thrills that do not far outlast the performance. Except for two, Beethoven's concertos represent his rare submission to routine and obligation, but those two are mightily interesting and enlightening, as glorious and hopeless efforts at realizing the impossible. The opening movements of both the "Emperor" and $G$ major Concertos are necessarily brilliant and highly ornamental by too firmly established precedent, like the Rondos, into which the slow movements so marvelously blend. And the fine themes are neither entirely satisfactory for orchestra nor piano, but rather a compromise, with mutual loss. The slow movements of each one remembers as most expressive, possessing that marked and individual character which sets a single work 
of art apart from all others, that makes them perhaps the most eloquent music for piano and orchestra, and the most happy in the use of the dual material. The secret of beauty and fitness in these instances may plausibly lie in the confinement of the orchestral part to the strings, with only a whispering use of the wood wind and a touch of horn in that of the "Emperor," but of the other, clear strings. So the whole discussion boils down to those few pages from the $G$ major Concerto, supreme in purity of tone and significance of content. It is successful because it treats contrast instead of compromise. The first voice of the string orchestra, terse, virile, and forbidding, is gradually softened, in the manner of the Overture to "Coriolanus," by the answering feminine influence of the tender, lovely, and persuasive piano chords, increasing in fantasia-like fulness of insinuating emotion, until the two are delicately merged. And this transcendental fragment is in manner completely removed from all custom of concerto-making-entirely simple in performance, with no ornament whatsoever, and requiring no more in the most humble of pianists than an appreciation of their beauty.

It is not this, but the music of executive ostentation which we would do without. The soloist habit holds partly through inertia, partly through the difficulty of financing orchestras, partly through the popular demand for celebrities. Should a joint movement for abolishing soloists be started among orchestral directors, conductors, and the celebrities themselves, should it be accomplished in a single important orchestra, municipal rivalry would surely make it spread, and the demand which needs no encouragement would necessarily turn to recitals for gratification.

But this is merely a single volley in the hunting down of an aspect of modern musical performance which it is the purpose of this article to pursue to its sources. You might consign technique to its subordinate part in the ultimate values of musical affairs, in spite of its over-emphasis, and hold up against the argument of technical freaks the great names of the geniuses of their instruments who are also humanly and musically broad and cultured. Yet genius refutes any axiom of human life; it is superhuman, and its feats are beyond belief-a Beethoven is everything musical at once, with a great, expansive, and reflective mind; he was a pianoforte virtuoso without having practised away more than a minimum part of his life and vitality for it, nor had he any desire to exhibit his skill further than the necessities of recognition and sustenance. Even Liszt branched into 
all musical departments, and was a creative virtuoso in orchestration, leaving no evidence of years of study and practice in the finding of this greatest part of his genius. Such things pass our understanding. And with the lesser geniuses of virtuosity, which nevertheless belong to our own day, we are more concerned in this discussion. The handful of the world's most noted pianists and violinists, at once supreme in technique, and in broad artistic development and insight, still hold to concertos because it is not in their unaided power to do away with the custom of playing with orchestras. With the abandonment of concertos, their gift to the world would by no means be lessened, and a devotion to the finest music obtainable rather than self-advancement, would lead violinists away from the musically unfruitful field of solo pieces, to combine with other musicians for the marvelously rich and neglected stores of violin sonatas and trios. Eighteenth century music yields endless beautiful ones; Beethoven's trios, in their loveliness, rarity, and exaltation, make a very close fourth to his symphonic and pianistic works and his string quartets, while the modern French and Belgian schools provide a most glorious list of both combinations from such as Franck, Lekeu, Chausson, d'Indy, Ravel, and Magnard, comprising an inheritance of which the world as yet scarcely appreciates the smallest part. What a bracing change from the nonentities of violin or 'cello recital programmes, and even from the endlessly hackneyed Chopin and Liszt of pianists! Nor can you say that chamber music touches the other extreme from self-exploitation-self-obliteration. It shears mainly the idiosyncratic parts of personal expression which are artistically superfluous. A mutually sympathetic performance, for instance, of Franck's Violin Sonata by two eminent musicians, involves no compromise in elasticity or phrasing, but rather inspiration in the joint interpretation of a beloved masterpiece. It encourages the best and the noblest, albeit the humblest, in a musician, and discourages competitive pride, chicanery, and ostentation of skill. And to have heard such a performance is to cherish in the memory a supreme rendering of supreme music, and closely to associate one's conception of the work with its finest interpreters. But these highest of musicians do not commit a merely negative crime in wasting their own imparting energies, and the appreciative energies of their audiences, upon pieces for display. Worse than this, they immediately set a false and sterile technical goal for musical aspirants the world over.

Prosper the amateurs! Let us not despise or even slight them, though they harass us as neighbors with their execrable 
scales, and oblige us as friends to attend their "coming out" recitals which crowd every season. Those who search among various races for our national music, seeking for some clue whereupon to attach a prophecy, had better turn to the younger generation in the settlements, conservatories, and elsewhere, poor and rich -the thousands of them who are whole-heartedly and intently devoting their careers to music. An inestimable amount of hopeful energy and activity, anxious for direction and advice, but under perfectly stupid teaching, and with a fundamentally unmusical society about them; a society utterly unlike the peoples of Germany, France, or Russia, where strong musical instinct is a common and not an unusual phenomenon, where amateur quartets permeate the countryside, and singing societies are on every hand; where musical development is coincident with daily experience and social contact, and not simply looked at askance by the uncomprehending on every side. What can the musical student do, so left to his own salvation, but look to the music that is going on-the concerts and operas wherein the star system is rife, where talent ready-made is imported from the old world like rare wine, and so pronounced upon by connoisseurs? Where we pay for the best, and receive the most famous. Where the public goes primarily to behold a remarkable tenor or violinist, regardless of what the music happens to be, and only the more content if it is such as to show him off to the best advantage. So, we find them all aspiring to be second Kreislers or Paderewskis, while before them stretch discouraging vistas of humanly and normally impossible technical achievement. And inevitably in their recitals comes some bombastic and baffling concert piece of Liszt, or the over-played "Appassionata" Sonata, or Bach's "Chaconne" for violin unaccompanied, works suited only to fully developed maturity, wherein the most direct and disparaging comparisons must arise in the minds of an audience fresh from finer performances of the same music. So it is a matter of "cut-throat competition" on identical grounds, resulting in an unceasing deluge of "Appassionatas" and thricehackneyed Chopin throughout the country. An appalling amount of admirable and highly accomplished technical achievement, and veritable thousands of excellently trained and hopeful pianists and violinists, all working desperately for the same limited end, and bound with the utmost certainty to fail, ninety-five per cent. of them, in that the number of far-famed virtuosi in the world is necessarily limited. That is an unescapable fact; unless they change their aim, they must, save a small handful, flounder from 
obscurity into oblivion to the tune of their beloved "Funeral March Sonata"! And the tragedy of such enormous wasted effort is not lessened by an evident futility in the success of the few. A good many of the younger virtuosi who have risen to recent fame may be consolidated, for the present purposes, into a sort of composite photograph : the typical viloinist is first heralded by the advertising methods of a circus, circulars of shameless exaggeration, and (in one case, at least, of the past season) a glaring canvas on a box frame driven about the streets; he comes upon the stage with the cramped and abnormal look of a recluse, unused to human society. His programme is a concerto or two, and various "sweetmeats" by various violinists, all of which he plays in exactly the same style and manner. His technique is swift, clever, accurate, and very nearly perfect; in fact, falls just perceptibly short of the older, topmost violinist whom he is emulating; his melodic tone is pure and beautiful. $\mathrm{He}$ is intensely musical by nature, alert and emotional, but his undivided attention is on his instrument, which he loves, and which this composer or that more or less successfully serves. Hence, it is not the music of the composer at all, in a particular sense, but simply technique and tone making; "ravishing tone," and overemphasized technique, which obscures the broader proportions with the pride of workmanship. The whole process is one of hard brilliance, which leaves the warmer musical impulses unstirred, in spite of the emotional absorption of the player. It is not a paradox-his enthusiasm probes no deeper than the fire of execution and the glow of tone. He has simply never gone deeper; to the best part of music he is cold and indifferent only because he is. ignorant. One of his sort stumbled upon the "Kreutzer Sonata" recently, and the result was a thick profusion of ornament, with Beethoven and the pianist alike effectually concealed beneath. With pianists, almost precisely the same is true. A high and prevalent standard of dexterity, but also a mechanical hardness and inability to unbend; a docile and apathetic obedience to the annotations of editors and the precepts of teachers. Violinists and pianists both are very apt to begin their recitals with Bach, not because Bach means anything to them, but because that is the custom among the famed. Unfortunate Bach is even more hardly treated than Chopin-a dance by the latter is at least a dance, or a fantasia a fantasia, but temporal remoteness deprives Bach of any throb of vitality in their ears; his dances, fantasias, and fugues alike become stiff and matter-of-fact finger exercises, with the steely glint of highly polished mechanism. 
The first thing to realize is, that in music no less than the other arts, teaching can only go a very short way. Beyond advice in the nimbling of fingers, and the fundamentals of bowing or pedalling, a teacher is a deterrent of self-reliance and initiative. As well teach a person breathing as phrasing! The reading of a particular piece can never be laid down-even the custom and precedent of its interpretation must be attested by the performer's own unaided instincts. As all great works of art have varying potentialities to appeal to succeeding periods and personalities, so some of Beethoven's later piano sonatas are as subjective as the part of Hamlet. They hold numberless readings for this nature and that, and far from the reach of didacticism, require much of the creator in their interpreters. Technical mastery bears one almost no way at all in such hallowed ground. Yet every upstart must have his plunge, and the result is like the Fotheringay's Ophelia, largely multiplied.

This is not saying, of course, that he who cannot play the "Hammerklavier" Sonata without desecration (few can indeed) had better renounce art on the spot. For musical success is certainly possible without preeminence, and within nearer grasp of many who could deflect their desperate technical ambitions. That scramble is largely a matter of misdirected effort. The majority who pound their lives away unrecognized over Liszt, would bring actual pleasure and benefits to themselves and their audiences by realizing that it is not of primary importance to be a "Leschetizky pupil," or to have studied in Europe; that true and remunerative artistic success is possible without far-flung fame; that as a relief from the stereotyped, variegated, and hackneyed programmes that abound, programmes of character, emphasizing fine music neglected from lack of exploiting utilities, would be greatly appreciated by musically discerning people. If young musicians would, in the same interest, combine more frequently for violin sonatas and trios, their public would begin to find out that hands which might falter under the requirements for poise and command from a piano sonata, will find confidence and support in the coöperative playing of chamber music; that such music brings out the best of one's abilities without making disagreeable and damning exaction, cruel exclusions and comparisons; that the simplest sort of music is a clear test of one's finer attainments, tone quality, delicacy of shading and sense of values, precision of rhythm and deftness of finger-work; that these traits are the more profoundly admired when "art conceals art," when they are not vaunted or accentuated, but selectively 
subordinated to the high, interpretative purpose of lofty music, beautifully rendered. The realization of this success is its own reward, and it is a state within the reach of thousands, if those thousands would admit their limitations, making music a secondary pursuit if need be, and besides their own enjoyment, delighting their friends, instead of driving them to flight with incessant and laborious finger-exercises.

This should be printed in gold lettering on the front of every piano manufactured: "In music, there is no rule outside the promptings of instinct. The beginning and end of musical development is not technique but natural impulse, and if you have not the impulse at the start, technical training will never bring it to you on this side of heaven. While piano technique is as necessary as the routine which accompanies every human activity, if you have not the self assertion and imagination to make it your liberator, to make skill a matter of second thought that you may freely explore your marvelous chosen field, if technique becomes not your humble tool but your master, then you had far better make no beginning, for your worth as a musician and artist is nil." 